Nama : Daud Hamonangan Tamunan

Kelas : X MIA 3

Mapel : Penjas

\title{
+ RESUME BOLA VOLI +
}

\section{A. Pengertian Permainan Bola Voli}

Permainan Bola Voli adalah permainan beregu yang masing-masing regu terdiri dari 6 orang dengan tujuan menjatuhkan bola kearah lawan dan mencapai game terlebih dahulu. Teknik Dasar : Service- Passing-Smash_Blok.

\section{B. Teknik Bola Voli}

1) Servis bawah

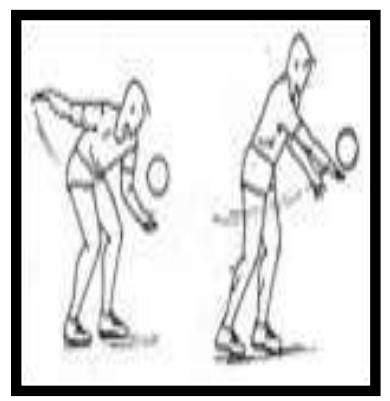

Adalah jenis Service ang paling mudah dilakukan. Kelemahan service bawah adalah bola mudah di terima oleh musuh.

2) Servis Atas

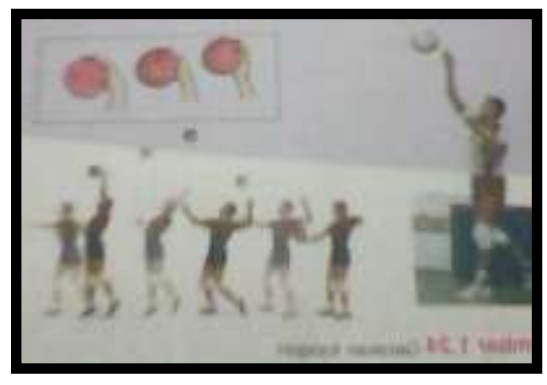

Service atas banyak variasi tekniknya :

a) Mengambang (floating).

b) Topspin

c) Mengambang melingkar 
3) Teknik Bola Voli Passing

*Passing bawah

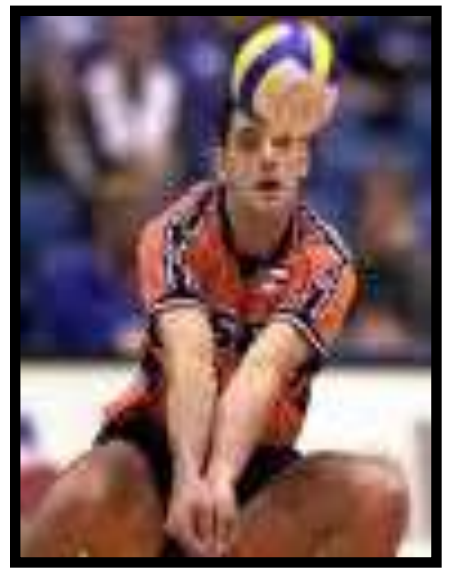

*Passing atas

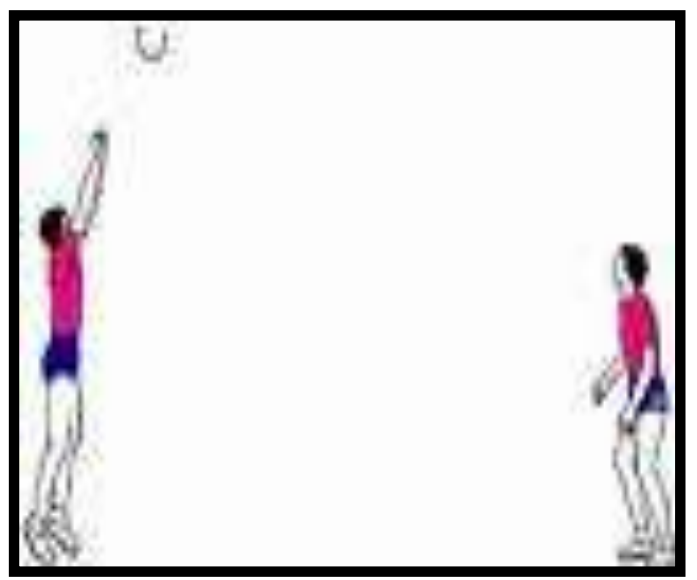

4) Teknik Bola Voli Smash

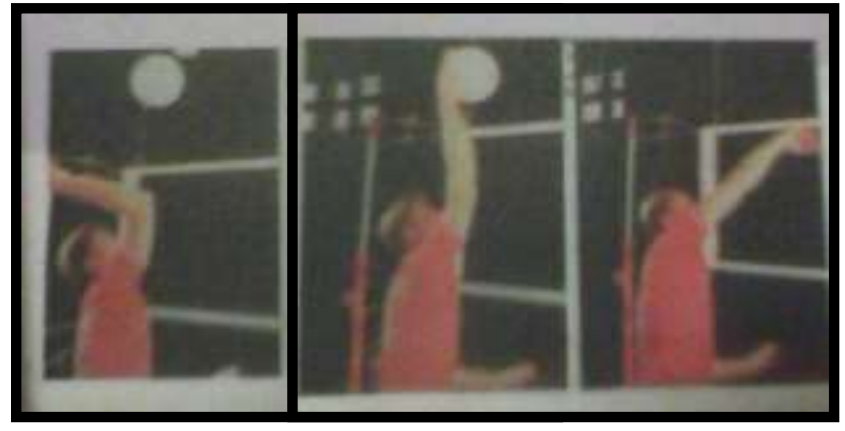

Smash : adalah pukulan yang tajam, keras dan menukik ke arah lapangan lawan.

Gerakan smash :

a) Awalan : melangkah 3-4 meter dari net.

b) Tolakan : langkah terakhir lompat dengan kedua kaki.

c) Sikap akhir : Pukul Bola sekeras-kersnya dan menukik. 


\section{5) Block (membendung)}

Tujuan :Membendung smash lawan. Dapat Dilakukan oleh satu, dua atau tiga pemain.

*Blok dilakukan 2 orang

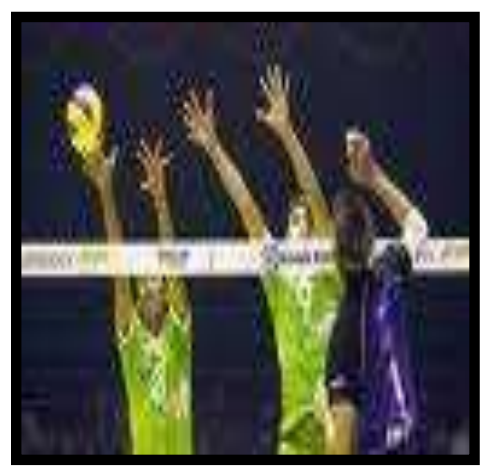

*Blok dilakukan oleh 1 orang

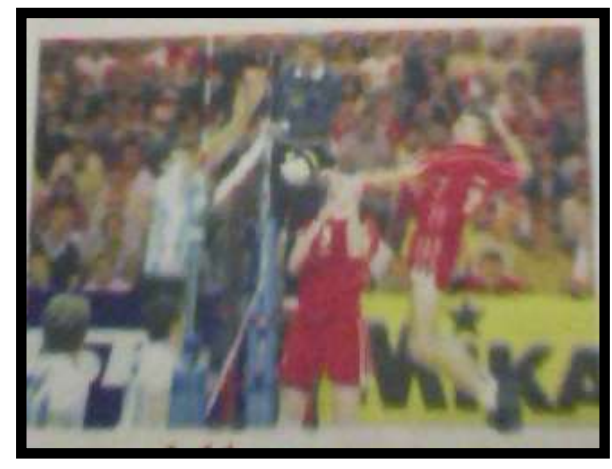

\section{CONTOH SOAL}

1) Apa yang kau ketahui tentang permainan bola voli ?

$=$ Permainan bola voli adalah suatu permainan yang menggunakan bola untuk di pantulkan (di-volley) di udara hilir mudik di atas net (jaring), dengan maksud menjatuhkan bola di dalam petak daerah permainan lawan untuk mencari kemenangan.

2) Sebutkan teknik-teknik dalam bola voli?

$=$ Teknik-teknik permainan Bola Voli antara lain :
a) Service :

1. Service atas

2. Srvice bawah

3. Service mengambang

4. Service Topspin

5. Service mengambang melingkar.
b) Passing :

1. Pasing atas

2. Passing Bawah
c) Smash
d) Block 
3) Sebutkan macam- macam teknik servis voli?

$=$ Teknik-teknik service dalam permainan Bola Voli :
a) Service atas
b) Srvice bawah
c) Service mengambang
d) Service Topspin
e) Service mengambang

+ TERIMAKASIH + 